\title{
Role of HACCP in Enhancing the Nature of Nourishment Things
}

\author{
Imtiyaz $\mathrm{RP}^{1 *}$ and Athar $\mathrm{AH}^{2}$ \\ ${ }^{1}$ Department of Chemistry, GDC Doru anantnag, India \\ ${ }^{2}$ Department of Chemistry, Jamia Millia Islamia, India
}

Submission: September 22, 2017; Published: October 25, 2017

"Corresponding author: Imtiyaz RP, Department of Chemistry, GDC Doru anantnag, Jammu \& Kashmir India-192211,

Email: imtiyazchemistry@gmail.com

\begin{abstract}
The nourishment handling industry in India is one of the biggest as far as generation, utilization, fare and development prospects. Vital subdivisions in the sustenance preparing enterprises are leafy foods handling, angle preparing, drain handling, meat and poultry handling, bundled/ helpful nourishment, mixed refreshments and soda pops and grain handling. In this mini review we are discussing the role of Hazard Analysis of Critical Control Points (HACCP) for improving the quality of food.
\end{abstract}

Keywords: Vital; Nourishment; HACCP

\section{Introduction}

According to national dairy improvement leading body of India the yearly drain creation status in Jammu And Kashmir State in the year 2014-2015 were 1951000 tones. Khyber Agro drain handling plant is arranged in region Pulwama, as Pulwama is most noteworthy drain delivering range in Kashmir. Drain generation in Pulwama, called "Anand of Kashmir", has expanded throughout the years and achieved more than eight lakh liters of drain in 2016. Pulwama produces 50 for each penny of the Valley's aggregate drain. The procedure for foundation of drain plant by Khyber Agro Farms Pvt.Ltd. was started in the year 1997 and the undertaking was finished and authorized by June 1998 as a biggest drain plant in the private division with its introduced limit of 60,000 liters of Milk for every day with an arrangement to deal with 1,20,000 liters for every day.

The plant is outfitted with most secluded innovation to deliver Homogenized, Pasteurized, Liquid drain of different assortments like conditioned drain, twofold conditioned Milk, Standard and full fat, comprehensive of Probiotic Dahi, Cream, cheddar and Ghee. The nature of drain acknowledged and dispatched meets certain foreordained measures. The drain experiences different procedures, for example, Clarification, Homogenization, Standardization and Pasteurization, to guarantee that it is ok for human utilization. Their thought process in following such strict quality measures is to guarantee that there is no sullying while at the same time handling or bundling. Accessibility of standard Hygienic Milk is an issue in many parts of the nation including the Kashmir valley. The organization chose to address this issue by propelling a self-supporting long haul venture for drain acquirement and preparing of drain. The point of the undertaking is to encourage and support the accessibility of a moderate answer for the sheltered and quality drain to the groups and to empower behavioral changes at the group level in great clean practices. GMP, QA, SPC, sanitation, cleanliness, nourishment wellbeing and ISO 9000-2005 are connected all through the assembling. They have advanced and executed extremely expand quality administration framework beginning from crude material to conveying completed items to the quality cognizant clients all through the world.

They have set up present day research facilities (counting microbiology, pesticide buildups and substantial metal investigation and tactile assessment) for examination and testing, upheld by the group of exceedingly qualified and experienced researchers and staff and furthermore settled R\&D focuses, both at the lab and in accumulation and chilling focuses. Drain is a characteristic and exceedingly nutritive and adjusted every day eat less carbs. It is a standout amongst other wellsprings 
of calcium and gives top notch protein, vitamins and different minerals. Drain and drain items are profoundly nutritious yet are most inclined to wellbeing dangers with various kind of risks that might be organic, substance and physical in nature.

This is principally because of unhygienic conditions and dishonorable preparing, dealing with and capacity conditions, the laborers in the business are ineffectively taught, unlicensed, untrained in sustenance cleanliness and they work under rough unsanitary conditions with practically no learning about the reasons for nourishment borne ailments. Unhygienic practices in cultivate units, at drain gathering focuses (MCC), preparing plants and amid post handling taking care of are related with a potential wellbeing dangers to purchasers because of the nearness of pathogens in the drain and to natural defilement. Tainting amid the retail offering procedure can additionally be ascribed to taking care of hardware (jars, tins, measuring jugs), air, staff and even customers.

Microbial defilement of drain and drain items must not surpass levels that could antagonistically influence time span of usability and, on the off chance that it does, it renders the drain unwholesome and consequently unfit for human utilization. Sustenance security in dairy industry is a logical train depicting milk obtainment, preparing, taking care of, capacity and promoting of drain and drain items in ways that forestall nourishment borne disease. This incorporates various schedules that ought to be taken after to keep away from possibly extreme wellbeing perils.

In considering business sector to shopper hones ,the typical idea is that sustenance should be sheltered in the market and the worry is protected conveyance of the nourishment to the customer the key standards of nourishment cleanliness incorporate counteracting sullying nourishment with pathogens spreading from individuals ,keeping up suitable temperature amid the preparing to murder pathogens, store drain and drain items at the correct temperature and keep up the temperature all through the evolved way of life Sustenance security and gauges expert of India ,set up under the Food wellbeing and standard act (2006) is the directing body identified with nourishment wellbeing and setting down of benchmarks of sustenance in India in the line of codex norms has characterized HACCP as a framework which assesses and controls risks which are noteworthy for nourishment wellbeing. All the more comprehensively it is a logical and discerning way to deal with nourishment wellbeing which examinations potential risks decides basic focuses in sustenance handling and creates checking systems to decide dangers distinguished are as a rule successfully controlled.

It improves nourishment wellbeing other than better utilization of assets and convenient reaction to issues.This is the motivation behind why this framework is broadly grasped by the sustenance and dairy ventures and by the administration administrative organizations around the globe as a most savvy intends to limit perils and, expanding item security. HACCP has been perceived as a successful and judicious method for guaranteeing sustenance wellbeing from essential creation to definite utilization, utilizing a "ranch to table" approach. HACCP was created by the Pillsbury Company alongside NASA in the 1960s.

It was initially created as a microbiological wellbeing framework to guarantee sustenance security for space explorers. Around then most sustenance wellbeing and quality control frameworks depended on finished result testing, which is a wasteful technique because of item squander. Along these lines, a precaution framework should have been created to give an abnormal state of nourishment security confirmation. The primary potential risks in most dairy items are microbiological Tranter 1990 and the dairy business has expanded its endeavors for quality and wellbeing affirmation through the advancement and usage of proactive projects, for example, HACCP.

HACCP is not "zero hazard" and does not dispose of the likelihood of a danger getting into the nourishment item. HACCP endeavors to diminish that plausibility to a worthy level. The best approach to dynamic sustenance wellbeing is to concentrate on anticipation of conceivable risks and to enhance the procedure. Risk Analysis Critical Control Points (HACCP) is an efficient technique that fills in as the establishment for guaranteeing nourishment security in the present day world. An essential advance in creating focused on approaches more steady of market investment by the dominant part of players is to lead chance examination (hazard appraisal, chance administration and hazard correspondence) on drain borne wellbeing dangers connected to the different generation and promoting frameworks.

There is a need to advance and increment execution of Hazard Analysis of Critical Control Points (HACCP) and shopper nourishment security training endeavors at all phases of the drain creation and advertising chain. The HACCP can be characterized as a framework which distinguishes, assesses and controls risks that are critical for nourishment security. On the off chance that HACCP is connected to drain promoting it ought to support the way to deal with drain wellbeing at all phases of the chain. Controlling the danger of human contamination with zoonotic infection would then be able to be controlled by Critical Control Points (CCPs) at various stages, bringing about a maintained lessening of pathogens at significant focuses.

Peril examination and basic control point framework (HACCP) has for some time been globally perceived and acknowledged as the framework for the compelling sustenance wellbeing administration. Peril examination basic control point frameworks must be founded on seven standards to be specific ,danger investigation, ID of basic control point,foundation of basic cutoff points for each CCP foundation of observing framework for each CCP ,foundation of restorative activities, foundation of check techniques and record keeping and documentation. 
The idea of Hazard Analysis in Critical Control Pointframework HACCP was displayed without precedent for 1971. The rules for this framework application were embraced in 1993, on the XXth session of Codex Alimentarius Commission. HACCP is characterized by the Codex Alimentarius commission as a framework that characterizes, assesses and controls imperative dangers from the sustenance wellbeing perspective. Towards the effective usage of the HACCP framework, every unit's administration needs to assign its own HACCP group, to make its representatives mindful of the advantages and expenses of HACCP. The advantages, other than nourishment security (fundamental guideline) are spoken to by a superior use of material assets and on-time arrangement of issues.

\section{Conclusion}

These days there is a regularly expanding purchaser interest for protected and excellent nourishments of delayed life. A few quality/wellbeing administration frameworks (e.g. HACCP) were produced for the nourishment business. The significance of executing such frameworks for rather biochemically precarious items like cheddar, and other drain item) portrayed by awesome assortment around the world, is evident It is essential to build up a sustenance security arrangement and technique for the execution of HACCP.

\section{Your next submission with Juniper Publishers} will reach you the below assets

- Quality Editorial service

- Swift Peer Review

- Reprints availability

- E-prints Service

- Manuscript Podcast for convenient understanding

- Global attainment for your research

- Manuscript accessibility in different formats ( Pdf, E-pub, Full Text, Audio)

- Unceasing customer service

Track the below URL for one-step submission https://juniperpublishers.com/online-submission.php 